\title{
ANALISIS PEMBAGIAN HASIL USAHA DALAM MENINGKATKAN PENGHASILAN JASA ANGGOTA KOPERASI SIMPAN PINJAM BERKAT CABANG PALOPO
}

\author{
Saharuddin $^{1}$, Haedar $^{2}$, Fitriani Syamsul ${ }^{3}$ \\ 1) Dosen Sekolah Tinggi Ilmu Ekonomi Muhammadiyah Palopo \\ ${ }^{2,3)}$ Dosen Sekolah Tinggi Ilmu Ekonomi Muhammadiyah Palopo
}

\begin{abstract}
Abstrak: Penelitian ini bertujuan untuk mengatahui dan menganalis pembagian Sisa Hasil Usaha dalam meningkatkan penghasilan jasa anggota KSP Berkat Cabang Palopo. Jenis data yang digunakan dalam penelitian ini adalah data kuantitatif yang merupakan data keuangan dari laporan keuangan KSP Berkat Cabang Palopo selama periode lima tahun mulai dari tahun 2010-2014. Analisis data yang digunakan dalam penelitian ini adalah rumus pembagian Sisa Hasil Usaha. Hasil penelitian menunjukkan bahwa dengan meningkatnya jumlah Sisa Hasil Usaha yang diperoleh koperasi maka penghasilan atas jasa anggota pun meningkat, pembagian Sisa Hasil Usaha dilakukan secara proporsional sebanding dengan jasa masing-masing anggota koperasi, semakin tinggi partisipasi anggota baik atas jasa usaha maupun simpanan maka Sisa Hasil Usaha yang diperoleh akan meningkat.
\end{abstract}

Kata kunci : Sisa Hasil Usaha, Jasa Anggota, Partisipasi Anggota

\section{PENDAHULUAN}

Koperasi bertujuan meningkatkan kesejahteraan anggota pada khususnya dan masyarakat pada umumnya, sekaligus sebagai bagian yang tidak terpisahkan dari tatanan perekonomian nasional yang demokratis dan berkeadilan berdasarkan pancasila dan UUD 1945. Undang-Undang Republik Indonesia No. 17 tahun 2012 tentang perkoperasian menjelaskan bahwa usaha koperasi terutama diarahkan pada bidang usaha yang terkait langsung dengan kepentingan anggota baik untuk menunjang usaha maupun kesejahteraannya. Maka pengelolaan koperasi harus dilakukan secara produktif, efektif dan efisien dalam arti koperasi harus mempunyai kemampuan mewujudkan pelayanan usaha yang dapat meningkatkan nilai tambah dan manfaat yang sebesar-besarnya pada anggota dengan tetap mempertimbangkan untuk memperoleh sisa hasil usaha.

Berdasarkan UU No.25 tahun 1992 Pasal 45 Ayat 1 Sisa Hasil Usaha merupakan pendapatan
Koperasi yang diperoleh dalam waktu satu tahun buku dikurangi dengan biaya, penyusutan dan kewajiban lainnya termasuk pajak dalam satu tahun buku yang bersangkutan. Jumlah Sisa Hasil Usaha yang diperoleh secara teratur serta kecenderungan meningkat merupakan faktor yang sangat penting dalam menilai keuntungan suatu koperasi. Stabilitas usaha menunjukkan kemampuan koperasi menggunakan modalnya secara efisien sehingga memperoleh keuntungan yang besar.

Sisa hasil usaha (SHU) yang diperoleh koperasi dibagikan kepada anggota secara adil sebanding dengan jasa masing-masing anggota. Karena Sisa Hasil Usaha merupakan salah satu daya tarik bagi seseorang untuk menjadi anggota koperasi tersebut dan akan mendorong anggota yang berpartisipasi pasif menjadi anggota yang aktif. Hal itu di sebabkan anggota yang berpartisipasi aktif akan mendapatkan jasa yang 
lebih dari pembagian sisa hasil usaha (SHU) koperasi tersebut.

KSP Berkat Cabang Palopo merupakan koperasi yang bergerak dalam jasa simpan pinjam. Koperasi ini didirikan dengan tujuan awal untuk kesejahteraan anggota masyarakat untuk membantu kebutuhannya dengan memberikan pinjaman, dengan cara menggiatkan tabungan dan mengatur pemberian-pemberian uang dengan bunga yang serendah-rendahnya. Sumber permodalan dari kopersi ini berupa simpanan para anggota koperasi.

\section{BAHAN DAN METODE}

Jenis data yang digunakan adalah data kuantitatif, adalah data penelitian yang berupa angka-angka, yang diperoleh dari laporan keuangan KSP Berkat Cabang Palopo yang terdiri dari laporan neraca tahun 2010-2014, dan laporan pembagian sisa hasil usaha tahun 2010-2014. Data sekunder, data yang diperoleh dari dokumendokumen serta sumber-sumber lainnya yang ada hubungannya dengan penelitian ini.

Populasi dalam penelitian ini adalah laporan keuangan KSP Berkat Cabang Palopo sejak tahun 1995-2014 yang berisikan pembagian Sisa Hasil Usaha. Sampel dari penelitian ini laporan keuangan tahun 2010-2014 KSP Berkat Cabang Palopo. Metode pengumpulan data yang digunakan yaitu Observasi, Wawancara, dan Studi Kepustakaan.

Metode analisis data dalam penelitian ini menggunakan rumus pembagian sisa hasil usaha per anggota (Sitio dan Halomoan, 2001:90) sebagai berikut :

$$
\mathrm{SHU}_{\mathrm{A}}=\mathrm{JUA}+\mathrm{JMA}
$$

Keterangan:

$$
\begin{aligned}
& \mathrm{SHU}_{\mathrm{A}}=\text { Sisa Hasil Usaha Anggota } \\
& \text { JUA = Jumlah Usaha Anggota } \\
& \text { JMA = Jasa Modal Anggota }
\end{aligned}
$$

Dengan menggunakan model matematika, SHU per anggota dapat dihitung sebagai berikut :

$$
\text { SHUpa }=\frac{V a}{V U K} x \mathrm{JUA}+\frac{\mathrm{sa}}{T M S} \times J M A
$$

Keterangan:

SHU pa : Sisa Hasil Usaha Per Anggota

JUA : Jasa Usaha Anggota

JMA : Jasa Modal Anggota

VA : Volume usaha Anggota (total transaksi anggota)

UK : Volume usaha total koperasi (total transaksi koperasi)

Sa : Jumlah simpanan anggota

TMS : Modal sendiri total (simpanan anggota total)

SHU koperasi dibagi sesuai dengan aturan yang telah ditetapkan pada Anggaran Dasar Koperasi yaitu :

- Dana candangan koperasi $45 \%$

- Jasa anggota $15 \%$

- Dana pengurus $10 \%$

- Dana karyawan $10 \%$

- Dana pendidikan $7,5 \%$

- Dana pembangunan $7,5 \%$

- Dana sosial 5\% 


\section{HASIL DAN PEMBAHASAN}

\section{Analisis Data dan Pembahasan}

\section{Perkembangan Sisa Hasil Usaha KSP Berkat Cabang Palopo tahun 2010-2014}

Sebagai suatu badan usaha, koperasi didalam menjalankan kegiatan usahanya tentu saja menghendaki untuk mendapatkan keuntungan atau Sisa Hasil Usaha yang cukup banyak maka Sisa Hasil Usaha tersebut dapat disisihkan sebagian untuk cadangan koperasi yang selanjutnya bisa dipergunakan untuk menambah modal koperasi.

Sisa hasil usaha mungkin tidak dapat dibagi habis, karena pembagian SHU dalam koperasi terbatas sesuai dengan tingkat bunga bank pemerintah dan rapat anggota memutuskan Sisa Hasil Usaha tahun buku yang bersangkutan tetap tinggal dalam rekening simpanan masing-masing anggota. Sisa hasil usaha yang tidak dibagi digunakan untuk pemupukan modal.

Perolehan Sisa Hasil Usaha akan terlihat pada data laporan keuangan dalam laporan tahunan koperasi pada tutup buku akhir tahun. Sisa Hasil Usaha memperlihatkan hasil yang telah dicapai oleh koperasi selama periode tertentu dalam satu tahun buku. Sebuah koperasi dikatakan baik atau berkembang bukan hanya dilihat dari perolehan Sisa Hasil Usaha saja tetapi juga dilihat dari rencana kerja pelaksanaan yang telah ditentukan dalam rapat anggota tahunan apakah rencana kerja tersebut bisa dilaksanakan secara keseluruhan.

Adapun perkembangan Sisa Hasil Usaha KSP Berkat Cabang Palopo Tahun Buku 20102014 sebagai berikut:

\section{Perkembangan Sisa Hasil Usaha KSP Berkat Cabang Palopo Tahun 2010-2014}

\begin{tabular}{|c|c|c|c|}
\hline TAH & SISA HASIL & \multicolumn{2}{|c|}{ PERKEMBANGAN } \\
\cline { 3 - 4 } UN & USAHA & RP & $\%$ \\
\hline 2010 & 404.411 .296 & - & - \\
\hline 2011 & 634.017 .536 & 229.606 .240 & 56,77 \\
\hline 2012 & 550.553 .816 & $(83.463 .720)$ & $(13,16)$ \\
\hline 2013 & 763.601 .088 & 213.047 .272 & 38,70 \\
\hline 2014 & 900.114 .502 & 136.513 .414 & 17,88 \\
\hline
\end{tabular}

Melihat pada tabel 2 diatas dapat kita lihat perkembangan Sisa Hasil Usaha KSP Berkat Cabang Palopo mengalami peningkatan dan penurunan. Dimana pada tahun 2011 SHU sebesar Rp. 634.017.536 di banding tahun 2010 sebesar Rp. 404.414.296, mengalami peningkatan sebesar Rp. 229.606.240 atau sebesar 56,77\%. Untuk tahun 2012 SHU sebesar Rp. 550.553 .816 mengalami penurunan sebesar Rp. -83.463 .720$ atau -13,16\%. Tahun 2013 SHU sebesar Rp. 763.601.088 mengalami peningkatan sebesar Rp. 213.047.272 atau 38,70\% dan pada tahun 2014 SHU sebesar Rp. 900.114.502 mengalami peningkatan sebesar Rp. 136.513.414 atau 17,88\%.

\section{Perkembangan Jumlah Anggota KSP Berkat Cabang Palopo Tahun 2010-2014}

Berikut ini adalah perkembangan jumlah anggota KSP Berkat Cabang Palopo dapat dilihat pada tabel dibawah ini:

Melihat pada tabel 3 diatas dapat kita

\begin{tabular}{|c|c|c|c|}
\hline TAHUN & ANGGOTA & \multicolumn{2}{|c|}{ PERKEMBANGAN } \\
\cline { 3 - 4 } & & ORANG & $\%$ \\
\hline 2010 & 414 & - & - \\
\hline 2011 & 520 & 106 & 25,60 \\
\hline 2012 & 605 & 85 & 16,35 \\
\hline 2013 & 712 & 107 & 17.69 \\
\hline 2014 & 804 & 92 & 11,44 \\
\hline
\end{tabular}


ketahui perkembangan jumlah anggota KSP Berkat Cabang Palopo mengalami peningkatan. Dimana pada tahun 2011 jumlah anggota sebesar 520 di banding tahun 2008 sebesar 414, mengalami peningkatan sebesar 106 orang atau sebesar $25,60 \%$. Untuk tahun 2012 jumlah anggota sebesar 605 mengalami peningkatan sebesar 85 atau 16,35\%. Tahun 2013 jumlah anggota sebesar 712 mengalami peningkatan sebesar 107 atau 17,69\% dan pada tahun 2014 jumlah anggota sebesar 804 dengan peningkatan 92 orang atau $11,44 \%$.

\section{Analisis Pembagian Sisa Hasil Usaha Dalam Meningkatkan Penghasilan Jasa Anggota KSP Berkat Cabang Palopo}

Seperti yang dikemukakan pada pembahasan terdahulu dan hipotesis yang ditetapkan dalam penelitian ini mengatakan bahwa pembagian Sisa Hasil Usaha secara proporsional dapat meningkatkan penghasilan jasa anggota KSP Berkat Cabang palopo. Untuk dapat mengetahui hipotesis tersebut maka peneliti akan menganalisanya dengan menggunakan rumus pembagian Sisa Hasil Usaha.

\begin{tabular}{|c|l|c|c|}
\hline No & Nama anggota & $\begin{array}{c}\text { Jumlah } \\
\text { simpanan }\end{array}$ & Jumlah jasa \\
\hline 1 & Daud Donde & 3.749 .452 & 2.271 .200 \\
2 & Sempaonganan & 3.490 .000 & 2.843 .000 \\
3 & Sarmince & 3.094 .187 & 1.640 .400 \\
4 & Sumarni & 1.786 .377 & 440.000 \\
5 & Elias. M, SE & 3.400 .000 & 3.396 .800 \\
6 & Isa & 3.652 .000 & 3.112 .600 \\
7 & Muh. Jafar & 1.322 .352 & 1.598 .800 \\
8 & Madding & 1.746 .620 & 762.000 \\
9 & Sukirman, BA & 3.410 .000 & 2.826 .600 \\
10 & St. Aminah Jufri & 3.140 .000 & 1.683 .400 \\
Dst & Dst & Dst & Dst \\
414 & & & \\
\hline \multicolumn{2}{|c|}{ Jumlah } & 560.879 .761 & 631.892 .650 \\
\hline
\end{tabular}

Sisa Hasil Usaha adalah Rp. 404.411.296 Sesuai dengan keputusan rapat anggota maka SHU dibagi atas:

Dana Cadangan $\quad: 45 \%$ x Rp. $404.411 .296=\mathrm{Rp}$. 181.985 .083

Jasa Anggota $\quad: 15 \%$ x Rp. $404.411 .296=$ Rp. 60.661 .694

Dana Pengurus $\quad: 10 \%$ x Rp. 404.411.296 = Rp. 40.441 .130

Dana Karyawan $\quad: 10 \%$ x Rp. $404.411 .296=$ Rp. 40.411 .130

Dana Pendidikan $\quad$ : 7,5\% x Rp 404.411.296 = Rp. 30.330 .847

Dana Pembangunan : 7,5\% x Rp 404.411.296= Rp 30.330.847

Dana Sosial $\quad: 5 \% \times$ Rp 404.411.296 = Rp. 20.220 .565

Berdasarkan keputusan rapat anggota, jasa anggota dibagi atas :

Jasa Usaha $56 \%$ x Rp. $60.661 .694=R p$. 33.970 .549

Jasa Modal 44\% $x \quad$ Rp. $60.661 .694=$ Rp.26.691.145

Rumus pembagian Sisa Hasil usaha :

$$
\text { SHUpa }=\frac{V a}{V U K} x \mathrm{JUA}+\frac{\mathrm{Sa}}{T M S} \times J M A
$$

Daud Donde :

SHU jasa : Va/VUK (JUA)

$2.271 .200 / 631.892 .650(33.970 .549)=122.300$

SHU simpanan (modal) : Sa/TMS (JMA)

$3.749 .452 / 560.879 .761(26.691 .145)=178.429$

Jadi sisa hasil usaha yang diperoleh Daud Donde :

$122.300+178.429=300.729$

Sempaonganan :

SHU jasa : Va/VUK (JUA)

$2.843 .000 / 631.892 .650(33.970 .549)=152.840$ 
SHU simpanan (modal) : Sa/TMS (JMA)

$3.490 .000 / 560.879 .761(26.691 .145)=166.082$

Jadi sisa hasil usaha yang diperoleh

Sempoanganan : $152.840+166.082=318.922$

Sarmince :

SHU jasa : Va/VUK (JUA)

$1.640 .400 / 631.892 .650(33.970 .549)=88.188$

SHU simpanan (modal) : Sa/TMS (JMA)

3.094.187/560.879.761 (26.691.145) = 147.246

Jadi sisa hasil usaha yang diperoleh Sarmince :

$88.188+147.246=235.434$

Sumarni

SHU jasa : Va/VUK (JUA)

$440.000 / 631.892 .650(33.970 .549)=23.654$

SHU simpanan (modal) : Sa/TMS (JMA)

$1.786 .377 / 560.879 .761(26.691 .45)=85.010$

Jadi sisa hasil usaha yang diperoleh Sumarni :

$23.654+85.010=108.664$

Elias. M, SE :

SHU jasa : Va/VUK (JUA)

$3.396 .800 / 631.892 .650(33.970 .549)=182.612$

SHU simpanan (modal) : Sa/TMS (JMA)

$3.400 .000 / 560.879 .761(26.691 .145)=161.799$

Jadi sisa hasil usaha yang diperoleh Elias. M, SE :

$182.612+161.799=344.411$

Isa :

SHU jasa : Va/VUK (JUA)

$3.112 .600 / 631.892 .650(33.970 .549)=167.333$

SHU simpanan (modal) : Sa/TMS (JMA)

$3.652 .000 / 560.879 .761(26.691 .145)=173.791$

Jadi sisa hasil usaha yang diperoleh Isa : $167.333+$

$173.791=311.124$

Muh. Jafar :

SHU jasa : Va/VUK (JUA)

$1.598 .800 / 631.892 .650(33.970 .549)=85.951$

SHU simpanan (modal) : Sa/TMS (JMA)
$1.322 .352 / 560.879 .761(26.691 .145)=62.928$

Jadi sisa hasil usaha yang diperoleh Muh. Jafar : $85.951+62.928=148.879$

Madding :

SHU jasa : Va/VUK (JUA)

$762.000 / 631.892 .650(33.970 .549)=40.965$

SHU simpanan (modal) : Sa/TMS (JMA)

$1.746 .620 / 560.879 .761(26.691 .145)=83.118$

Jadi sisa hasil usaha yang diperoleh Madding : $40.965+83.118=124.083$

Sukirman, BA :

SHU jasa : Va/VUK (JUA)

$2.826 .600 / 631.892 .650(33.970 .549)=151.958$

SHU simpanan (modal) : Sa/TMS (JMA)

$3.410 .000 / 560.879 .761(26.691 .145)=162.275$

Jadi sisa hasil usaha yang diperoleh Sukirman BA

$: 151.958+162.275=314.233$

St. Aminah Jufri :

SHU jasa : Va/VUK (JUA)

$1.683 .400 / 631.892 .650(33.970 .549)=90.499$

SHU simpanan (modal) : Sa/TMS (JMA)

$3.140 .000 / 560.879 .761(26.691 .145)=149.426$

Jadi sisa hasil usaha yang diperoleh St. Aminah Jufri : $90.499+149.426=239.925$

Dst hingga 414 anggota

Melihat tabel diatas serta proses perhitungan Sisa Hasil Usaha, maka pembagian Sisa Hasil Usaha telah dilakukan secara proporsional sebanding dengan jasa masing-masing anggota. Semakin tinggi partisipasi anggota baik atas jasa usaha maupun simpanan maka Sisa Hasil Usaha yang diperoleh akan semakin besar. 


\section{Pembagian Sisa Hasil Usaha KSP Berkat Cabag Palopo Tahun 2011}

\begin{tabular}{|l|l|l|l|}
\hline No & Nama anggota & $\begin{array}{l}\text { Jumlah } \\
\text { simpanan }\end{array}$ & Jumlah jasa \\
\hline 1 & Renaldi, SE. MM & 3.400 .000 & 8.133 .500 \\
2 & Hj. Hasdal & 3.400 .000 & 4.537 .100 \\
3 & Yahya Manda & 3.373 .991 & 2.640 .000 \\
4 & Lukas Sampe & 2.320 .000 & 1.680 .000 \\
5 & Djasnah & 1.993 .658 & 790.000 \\
6 & Agustina Tolla & 3.700 .000 & 3.742 .400 \\
7 & M.Kasim. N & 2.333 .937 & 2.400 .000 \\
8 & Gaffar & 3.662 .663 & 5.400 .000 \\
9 & Hamidardi. BSW & 1.541 .863 & 759.500 \\
10 & Nurcahaya & 3.880 .000 & 800.700 \\
Dst & Dst & Dst & Dst \\
520 & & 811.600 .472 & 990.652 .400 \\
\hline \multicolumn{4}{|l|}{} \\
\hline
\end{tabular}

Sisa Hasil Usaha adalah Rp. 634.017.536

Sesuai dengan keputusan rapat anggota maka sisa hasil usaha dibagi atas:

Dana Cadangan $\quad$ : 45\% x Rp. 634.017.536 = Rp. 285.307.891

Jasa Anggota : 15\% x Rp. 634.017.536 =Rp. 95.102 .630

Dana Pengurus $\quad: 10 \%$ x Rp. 634.017.536 = Rp. 63.401 .754

Dana Karyawan : $10 \%$ x Rp. $634.017 .536=$ Rp. 63.401 .754

Dana Pendidikan : 7,5\% x Rp 634.017.536=Rp. 47.551 .315

Dana Pembangunan : 7,5\% x Rp 634.017.536 = Rp 47.551.315

Dana Sosial $\quad: 5 \% \quad x \quad \operatorname{Rp} 634.017 .537=\mathrm{Rp}$. 31.700 .876
Berdasarkan keputusan rapat anggota, jasa anggota dibagi atas :

Jasa Usaha $56 \%$ x Rp. $95.102 .630=\mathrm{Rp}$. 53.275 .473

Jasa Modal 44\% $x \quad$ Rp. $95.102 .630=$ Rp.41.845.157

Rumus pembagian Sisa Hasil usaha :

$$
\text { SHUpa }=\frac{V a}{V U K} x \mathrm{JUA}+\frac{\mathrm{Sa}}{T M S} x J M A
$$

Renaldi, SE. MM :

SHU jasa : Va/VUK (JUA)

$8.133 .500 / 990.652 .400(53.257 .473)=437.257$

SHU simpanan (modal) : Sa/TMS (JMA)

$3.400 .000 / 811.600 .472(41.845 .157)=175.300$

Jadi sisa hasil usaha yang diperoleh Renaldi, SE.MM : $437.257+175.300=612.557$

2. Hj. Hasdal :

SHU jasa : Va/VUK (JUA)

$4.537 .100 / 990.652 .400(53.257 .473)=234.915$

SHU simpanan (modal) : Sa/TMS (JMA)

$3.400 .000 / 811.600 .472(41.845 .157)=175.300$

Jadi sisa hasil usaha yang diperoleh $\mathrm{Hj}$. Hasdal : $234.915+175.300=419.215$

Yahya Manda :

SHU jasa : Va/VUK (JUA)

$2.640 .000 / 990.652 .400(53.257 .473)=141.926$

SHU simpanan (modal) : Sa/TMS (JMA)

3.373.991/811.600.472 $(41,845.157)=173.959$

Jadi sisa hasil usaha yang diperoleh Yahya Manda

$: 141.926+173.959=315.885$

Lukas Sampe :

SHU jasa : Va/VUK (JUA)

$1.680 .000 / 990.652 .400(53.257 .473)=90.317$

SHU simpanan (modal) : Sa/TMS (JMA)

$2.320 .000 / 811.600 .472(41.845 .157)=119.616$ 
Jadi sisa hasil usaha yang diperoleh Lukas Sampe :

$90.317+119.616=209.933$

Djasnah :

SHU jasa : Va/VUK (JUA)

$790.000 / 990.652 .400(53.257 .473)=42.470$

SHU simpanan (modal) : Sa/TMS (JMA)

$1.993 .658 / 811.600 .472(41.845 .157)=102.791$

Jadi sisa hasil usaha yang diperoleh Djasnah :

$42.470+102.791=145.261$

Agustina Tolla

SHU jasa : Va/VUK (JUA)

$3.742 .400 / 990.652 .400(53.257 .479)=201.191$

SHU simpanan (modal) : Sa/TMS (JMA)

$3.700 .000 / 811.600 .472(41.845 .157)=190.768$

Jadi sisa hasil usaha yang diperoleh Agustina Tolla

$: 201.191+190.768=391.959$

M. Kasim N :

SHU jasa : Va/VUK (JUA)

$2.400 .000 / 990.652 .400(53.257 .473)=120.024$

SHU simpanan (modal) : Sa/TMS (JMA)

$2.333 .937 / 811.600 .472(41.845 .157)=120.335$

Jadi sisa hasil usaha yang diperoleh M. Kasim N :

$120.024+120.335=240.379$

Gaffar :

SHU jasa : Va/VUK (JUA)

$5.400 .000 / 990.652 .400(53.257 .473)=290.304$

SHU simpanan (modal) : Sa/TMS (JMA)

$3.662 .663 / 811.600 .472(41.845 .157)=188.843$

Jadi sisa hasil usaha yang diperoleh Gaffar:

$290.304+188.843=479.147$

Hamidardi, BSW :

SHU jasa : Va/VUK (JUA)

$759.500 / 990.652 .400(53.257 .473)=40.831$

SHU simpanan (modal) : Sa/TMS (JMA)

$1.541 .863 / 811.600 .472(41.845 .157)=79.497$
Jadi sisa hasil usaha yang diperoleh Hamidardi : $40.831+79.497=120.328$

Nurcahaya :

SHU jasa : Va/VUK (JUA)

$800.700 / 990.652 .400(53.257 .473)=43.046$

SHU simpanan (modal) : Sa/TMS (JMA)

$3.880 .000 / 811.600 .472(41.845 .157)=195.234$

Jadi sisa hasil usaha yang diperoleh Nurcahaya :

$43.046+195.234=234.094$

Dst hingga 520 Anggota

Melihat tabel diatas serta proses perhitungan Sisa Hasil Usaha, maka pembagian Sisa Hasil Usaha telah dilakukan secara proporsional sebanding dengan jasa masing-masing anggota. Semakin tinggi partisipasi anggota baik atas jasa usaha maupun simpanan maka Sisa Hasil Usaha yang diperoleh akan semakin besar.

\section{Pembagian Sisa Hasil Usaha KSP Berkat Cabang Palopo Tahun 2012}

\begin{tabular}{|c|l|c|c|}
\hline No & Nama anggota & $\begin{array}{c}\text { Jumlah } \\
\text { simpanan }\end{array}$ & Jumlah jasa \\
\hline 1 & Muh. Yasing & 3.598 .515 & 4.403 .000 \\
2 & Oktofina & 3.400 .000 & 4.183 .400 \\
3 & Hajerah, S.Pd & 3.570 .000 & 1.546 .737 \\
4 & Murniati & 3.400 .000 & 7.064 .000 \\
5 & Naomi Tombi & 4.150 .000 & 3.067 .400 \\
6 & Amirullah & 2.620 .000 & 1.320 .000 \\
7 & Madjid, S.Pd & 2.320 .569 & 833.400 \\
8 & Sarsinah & 6.122 .919 & 5.300 .900 \\
9 & A. Fadriani & 2.430 .000 & 3.834 .000 \\
10 & Rakhmawati, S.Ag & 3.400 .000 & 4.181 .600 \\
Dst & Dst & Dst & Dst \\
605 & & & \\
\hline \multicolumn{2}{|c|}{ Jumlah } & 1.102 .592 .1 & 1.391 .490 .33 \\
& \multicolumn{2}{|c}{} \\
\hline
\end{tabular}

Sisa Hasil Usaha adalah Rp. 550.553.816 Sesuai dengan keputusan rapat anggota maka sisa hasil usaha dibagi atas: 
Dana Cadangan : 45\% x Rp. 550.553.816 = Rp. 247.749.217

Jasa Anggota : $15 \%$ x Rp. 550.553.816 = Rp. 82.583 .072

Dana Pengurus $\quad: 10 \%$ x Rp. 550.553.816 = Rp. 55.055 .382

Dana Karyawan : $10 \%$ x Rp. $550.553 .816=$ Rp. 55.055.382

Dana Pendidikan $\quad$ : 7,5\% x Rp 550.553.816= Rp. 41.291 .536

Dana Pembangunan : 7,5\% x Rp 550.553.816= Rp 41.291.536

Dana Sosial $\quad: 5 \% \quad x \quad R p 550.553 .816=R p$. 27.527.691

Berdasarkan keputusan rapat anggota, jasa anggota dibagi atas :

Jasa Usaha $56 \%$ x Rp. 82.583.072 = Rp. 46.246 .520

Jasa Modal $44 \% \quad \mathrm{x} \quad$ Rp. $82.583 .072=$ Rp.36.336.552

Rumus pembagian Sisa Hasil usaha :

$$
\text { SHUpa }=\frac{V a}{V U K} x \mathrm{JUA}+\frac{\mathrm{Sa}}{T M S} \times J M A
$$

Muh. Yasing :

SHU jasa : Va/VUK (JUA)

$4.403 .000 / 1.391 .490 .337(46.246 .520)=146.335$

SHU simpanan (modal) : Sa/TMS (JMA)

3.598.515/1.102.592.164 (36.336.552) $=118.591$

Jadi sisa hasil usaha yang diperoleh Muh. Yasing :

$146.335+118.591=264.926$

Oktofina :

SHU jasa : Va/VUK (JUA)

$4.183 .400 / 1.391 .490 .337(46.246 .520)=139.036$

SHU simpanan (modal) : Sa/TMS (JMA)

3.400.000/1.102.592.164 (36.336.552) = 112.049
Jadi sisa hasil usaha yang diperoleh Oktofina : $139.036+112.049=251.085$

Hajerah, S.Pd :

SHU jasa : Va/VUK (JUA)

1.546.737/1.391.490.337 $(46.246 .520)=51.406$

SHU simpanan (modal) : Sa/TMS (JMA)

$3.570 .000 / 1.102 .592 .164(36.336 .552)=117.651$

Jadi sisa hasil usaha yang diperoleh Hajerah : $51.406+117.651=169.057$

Murniati :

SHU jasa : Va/VUK (JUA)

7.064.000/1.391.490.337 $(46.246 .520)=234.774$

SHU simpanan (modal) : Sa/TMS (JMA)

$3.400 .000 / 1.102 .592 .164(36.336 .552)=112.049$

Jadi sisa hasil usaha yang diperoleh Murniati :

$234.774+112.049=346.823$

Naomi Tombi :

SHU jasa : Va/VUK (JUA)

$3.067 .400 / 1.391 .490 .337(46.246 .520)=101.946$

SHU simpanan (modal) : Sa/TMS (JMA)

$4.150 .000 / 1.102 .592 .164(36.336 .552)=136.766$

Jadi sisa hasil usaha yang diperoleh Naomi Tombi

$: 101.946+136.766=238.712$

Amirullah :

SHU jasa : Va/VUK (JUA)

$1.320 .000 / 1.391 .490 .337(46.246 .520)=43.871$

SHU simpanan (modal) : Sa/TMS (JMA)

$2.620 .000 / 1.102 .592 .164(36.336 .552)=86.334$

Jadi sisa hasil usaha yang diperoleh Amirullah :

$43.871+86.334=174.086$

Madjid, S.Pd :

SHU jasa : Va/VUK (JUA)

$833.400 / 1.391 .490 .337(46.246 .520)=27.698$

SHU simpanan (modal) : Sa/TMS (JMA)

$2.320 .569 / 1.102 .592 .164(36.336 .552)=76.477$ 
Jadi sisa hasil usaha yang diperoleh Madjid, S.Pd :

$27.698+76.477=104.166$

Sarsinah :

SHU jasa : Va/VUK (JUA)

$5.300 .900 / 1.391 .490 .337(46.246 .520)=176.177$

SHU simpanan (modal) : Sa/TMS (JMA)

6.122.919/1.102.592.164 (36.336.552) $=201.784$

Jadi sisa hasil usaha yang diperoleh Sarsinah :

$176.177+201.784=377.961$

A. Fadriani :

SHU jasa : Va/VUK (JUA)

3.834.000/1.391.490.337 $(46.246 .520)=127.424$

SHU simpanan (modal) : Sa/TMS (JMA)

$2.430 .000 / 1.102 .592 .164(36.336 .552)=80.082$

Jadi sisa hasil usaha yang diperoleh A. Fadriani :

$127.424+80.082=207.506$

Rakhmawati, S.Ag

SHU jasa : Va/VUK (JUA)

4.181.600/1.391.490.337 $(46.246 .520)=138.977$

SHU simpanan (modal) : Sa/TMS (JMA)

3.400.000/1.102.592.164 (36.336.552) = 112.049

Jadi sisa hasil usaha yang diperoleh Rakhmawati :

$138.977+112.049=251.026$

Dst hingga 605 Anggota

Melihat tabel diatas serta proses perhitungan

Sisa Hasil Usaha, maka pembagian Sisa Hasil Usaha telah dilakukan secara proporsional sebanding dengan jasa masing-masing anggota.

Semakin tinggi partisipasi anggota baik atas jasa usaha maupun simpanan maka Sisa Hasil Usaha yang diperoleh akan semakin besar.

\section{Pembagian Sisa Hasil Usaha KSP Berkat Cabang Palopo Tahun 2013}

\begin{tabular}{|c|l|c|c|}
\hline No & Nama anggota & $\begin{array}{c}\text { Jumlah } \\
\text { simpanan }\end{array}$ & Jumlah jasa \\
\hline 1 & Bunga & 2.266 .187 & 1.794 .400 \\
2 & Rohana Syam & 2.404 .084 & 1.200 .000 \\
3 & Yusub Dori & 2.368 .000 & 2.352 .900 \\
4 & M. Yusuf & 3.400 .000 & 3.762 .500 \\
5 & A. Sam Sam & 2.210 .000 & 3.299 .000 \\
6 & Sarwana & 3.246 .107 & 2.553 .000 \\
7 & Ambo Latjang & 4.148 .271 & 1.168 .900 \\
8 & Muchlis & 3.545 .778 & 1.269 .400 \\
9 & Hadrawis & 3.700 .000 & 2.400 .000 \\
10 & Sudirman & 3.700 .000 & 2.295 .200 \\
Dst & Dst & Dst & Dst \\
712 & \multicolumn{2}{|c|}{} & \\
\hline \multicolumn{2}{|c|}{ Jumlah } & 1.468 .913 .65 & 1.755 .626 .70 \\
& \multicolumn{2}{|c}{} \\
\hline
\end{tabular}

Sisa Hasil Usaha adalah Rp. 763.601.088 Sesuai dengan keputusan rapat anggota maka sisa hasil usaha dibagi atas:

Dana Cadangan $\quad: 45 \%$ x Rp. $763.601 .088=\mathrm{Rp}$. 343.620 .490

Jasa Anggota : 15\% x Rp. $763.601 .088=\mathrm{Rp}$. 114.540 .163

Dana Pengurus $\quad: 10 \%$ x Rp. 763.601.088 = Rp. 76.360 .109

Dana Karyawan $\quad: 10 \%$ x Rp. $763.601 .088=\mathrm{Rp}$. 76.360.109

Dana Pendidikan : 7,5\% x Rp 763.601.088 = Rp. 57.720 .081

Dana Pembangunan : 7,5\% x Rp 763.601.088= Rp 57.720.081

Dana Sosial $\quad: 5 \% \quad x \quad R p 763.601 .088=R p$. 38.180 .054

Berdasarkan keputusan rapat anggota, jasa anggota dibagi atas :

Jasa Usaha $56 \%$ x Rp. $114.540 .163=\mathrm{Rp}$. 64.142 .491 
Jasa Modal 44\% $x$ Rp. 114.540.163= Rp.50.397.672

Rumus pembagian Sisa Hasil usaha :

$$
\text { SHUpa }=\frac{V a}{V U K} x \mathrm{JUA}+\frac{\mathrm{Sa}}{T M S} x J M A
$$

Bunga :

\section{SHU jasa : Va/VUK (JUA)}

$1.794 .400 / 1.755 .626 .700(64.142 .491)=65.559$

SHU simpanan (modal) : Sa/TMS (JMA)

2.266.187/1.468.913.652 (50.397.672) $=77.752$

Jadi sisa hasil usaha yang diperoleh Bunga : $65.559+77.752=143.311$

Rohana Syam :

SHU jasa : Va/VUK (JUA)

$1.200 .000 / 1.755 .626 .700(64.142 .491)=43.834$

SHU simpanan (modal) : Sa/TMS (JMA)

$2.404 .084 / 1.468 .913 .652(50.397 .672)=82.483$

Jadi sisa hasil usaha yang diperoleh Rohana Syam $: 43.834+82.483=126.326$

Yusub Dori :

SHU jasa : Va/VUK (JUA)

2.352.900/1.755.626.700 (64.142.491) = 85.964

SHU simpanan (modal) : Sa/TMS (JMA)

2.368.000/1.468.913.652 (50.397.672) = 81.245

Jadi sisa hasil usaha yang diperoleh Yusub Dori :

$85.964+81.245=167.209$

M. Yusuf :

SHU jasa : Va/VUK (JUA)

$3.762 .500 / 1.755 .626 .700(64.142 .491)=137.464$

SHU simpanan (modal) : Sa/TMS (JMA)

$3.400 .000 / 1.468 .913 .652(50.397 .672)=116.652$

Jadi sisa hasil usaha yang diperoleh M. Yusuf :

$137.464+116.652=254.116$

A. Sam Sam :

SHU jasa : Va/VUK (JUA)

$3.299 .000 / 1.755 .626 .700(64.142 .491)=120.530$
SHU simpanan (modal) : Sa/TMS (JMA)

$2.210 .000 / 1.468 .913 .652(50.397 .672)=75.824$

Jadi sisa hasil usaha yang diperoleh A. Sam Sam :

$120.530+75.824=196.354$

Sarwana :

SHU jasa : Va/VUK (JUA)

2.553.000/1.755.626.700 (64.142.491) = 93.275

SHU simpanan (modal) : Sa/TMS (JMA)

$3.246 .107 / 1.468 .913 .652(50.397 .672)=111.372$

Jadi sisa hasil usaha yang diperoleh Sarwana : $93.275+111.372=204.647$

Ambo Latjang :

SHU jasa : Va/VUK (JUA)

$1.168 .900 / 1.755 .626 .700(64.142 .491)=42.706$

SHU simpanan (modal) : Sa/TMS (JMA)

4.148.271/1.468.913.652 (50.397.672) $=142.325$

Jadi sisa hasil usaha yang diperoleh Ambo Latjang

$: 42.706+142.325=185.031$

Muchlis :

SHU jasa : Va/VUK (JUA)

1.269.400/1.755.626.700 (64.142.491) $=46.378$

SHU simpanan (modal) : Sa/TMS (JMA)

$3.545 .778 / 1.468 .913 .652(50.397 .672)=121.654$

Jadi sisa hasil usaha yang diperoleh Muchlis :

$46.378+121.654=168.032$

Hadrawis :

SHU jasa : Va/VUK (JUA)

$2.400 .000 / 1.755 .626 .700(64.142 .491)=87.645$

SHU simpanan (modal) : Sa/TMS (JMA)

$3.700 .000 / 1.468 .913 .652(50.397 .672)=126.945$

Jadi sisa hasil usaha yang diperoleh Hadrawis :

$87.645+126.945=214.590$

Sudirman :

SHU jasa : Va/VUK (JUA)

$2.295 .200 / 1.755 .626 .700(64.142 .491)=83.856$

SHU simpanan (modal) : Sa/TMS (JMA) 
$3.700 .000 / 1.468 .913 .652(50.397 .672)=126.945$

Jadi sisa hasil usaha yang diperoleh Sudirman:

$83.856+126.945=210.801$

Dst hingga 712 Anggota

Melihat tabel diatas serta proses perhitungan Sisa Hasil Usaha, maka pembagian Sisa Hasil Usaha telah dilakukan secara proporsional sebanding dengan jasa masing-masing anggota. Semakin tinggi partisipasi anggota baik atas jasa usaha maupun simpanan maka Sisa Hasil Usaha yang diperoleh akan semakin besar.

\section{Pembagian Sisa Hasil Usaha KSP Berkat Cabang Palopo Tahun 2014}

\begin{tabular}{|c|l|c|c|}
\hline No & Nama anggota & $\begin{array}{c}\text { Jumlah } \\
\text { simpanan }\end{array}$ & Jumlah jasa \\
\hline 1 & Sumarni & 3.448 .553 & 1.109 .200 \\
2 & Elias M. SE & 4.415 .524 & 149.300 \\
3 & Sukirman BA & 6.413 .500 & 2.939 .700 \\
4 & Lukas Sampe & 3.471 .000 & 3.360 .000 \\
5 & Frans Fredy & 4.150 .000 & 4.713 .100 \\
6 & W.BA & 3.125 .023 & 4.800 .000 \\
7 & Markus & 3.750 .000 & 5.080 .100 \\
8 & Maemunah & 4.762 .438 & 3.789 .000 \\
9 & Rumampuk CH & 3.442 .230 & 2.277 .600 \\
10 & Aisyah & 750.127 & 3.415 .400 \\
Ds & Tambaru & dst & dst \\
t & Dst & & \\
80 & & & \\
4 & & 1.940 .888 .7 & 2.358 .946 .3 \\
\hline & Jumlah & 20 & 03 \\
\hline
\end{tabular}

Sisa Hasil Usaha adalah Rp. 900.114.502

Sesuai dengan keputusan rapat anggota maka sisa hasil usaha dibagi atas:

Dana Cadangan $\quad: 45 \%$ x Rp. $900.114 .502=\mathrm{Rp}$. 405.051 .526

Jasa Anggota : 15\% x Rp. 900.114.502 = Rp. 135.017.175

Dana Pengurus $\quad: 10 \%$ x Rp. $900.114 .502=\mathrm{Rp}$. 90.011 .450
Dana Karyawan $\quad: 10 \%$ x Rp. $900.114 .502=$ Rp. 90.011 .450

Dana Pendidikan $\quad$ : 7,5\% x Rp 900.114.502 = Rp. 67.508 .588

Dana Pembangunan : 7,5\% x Rp 900.114.502 = Rp 67.508.588

Dana Sosial $\quad: 5 \% \quad x \quad R p 900.114 .502=\mathrm{Rp}$. 45.005 .725

Berdasarkan keputusan rapat anggota, jasa anggota dibagi atas :

Jasa Usaha $56 \%$ x Rp. 135.017.175 = Rp. 75.609 .618

Jasa Modal 44\% x Rp. 135.017.175 = 59.407.557

Rumus pembagian Sisa Hasil usaha :

$$
\text { SHUpa }=\frac{V a}{V U K} x \mathrm{JUA}+\frac{\mathrm{Sa}}{T M S} x J M A
$$

Sumarni:

SHU jasa : Va/VUK (JUA)

1.109.200/2.358.946.303 (75.609.618) $=35.552$

SHU simpanan (modal) : Sa/TMS (JMA)

$3.448,553 / 1.940 .880 .720(59.407 .557)=105.555$

Jadi sisa hasil usaha yang diperoleh Sumarni : $35.552+105.555=141.107$

Elias. M. SE

SHU jasa : Va/VUK (JUA)

$149.300 / 2.358 .946 .303(75.609 .618)=4.785$

SHU simpanan (modal) : Sa/TMS (JMA)

$4.415 .524 / 1.940 .880 .720(59.407 .557)=137.418$

Jadi sisa hasil usaha yang diperoleh Elias M. SE :

$4.785+137.418=142.203$

Sukirman BA

SHU jasa : Va/VUK (JUA)

2.939.700/2.358.946.303 (75.609.618) $=94.224$

SHU simpanan (modal) : Sa/TMS (JMA)

$6.413 .500 / 1.940 .880 .720(59.407 .557)=196.307$ 
Jadi sisa hasil usaha yang diperoleh Sukirman BA

: $94.224+196.307=290.531$

Lukas Sampe

SHU jasa : Va/VUK (JUA)

3.360.000/2.358.946.303 $(75.609 .618)=107.696$

SHU simpanan (modal) : Sa/TMS (JMA)

$3.471 .000 / 1.940 .880 .720(59.407 .557)=106.242$

Jadi sisa hasil usaha yang diperoleh Lukas Sampe:

$107.696+106.242=213.938$

Frans Fredy W. BA

SHU jasa : Va/VUK (JUA)

4.713.100/2.358.946.303 (75.609.618) $=151.066$

SHU simpanan (modal) : Sa/TMS (JMA)

$4.150 .000 / 1.940 .880 .720(59.407 .557)=127.025$

Jadi sisa hasil usaha yang diperoleh Frans Fredy

W. BA : $151.066+127.025=278.091$

Markus

SHU jasa : Va/VUK (JUA)

4.800.000/2.358.946.303 $(75.609 .618)=153.851$

SHU simpanan (modal) : Sa/TMS (JMA)

$3.125 .023 / 1.940 .880 .720(59.407 .557)=95.632$

Jadi sisa hasil usaha yang diperoleh Markus :

$153.851+95.632=249.483$

Maemunah

SHU jasa : Va/VUK (JUA)

$5.080 .100 / 2.358 .946 .303(75.609 .618)=162.829$

SHU simpanan (modal) : Sa/TMS (JMA)

$3.750 .000 / 1.940 .880 .720(59.407 .557)=114.782$

Jadi sisa hasil usaha yang diperoleh Maemunah :

$162.829+114.782=277.611$

Rumampuk $\mathrm{CH}$

SHU jasa : Va/VUK (JUA)

3.789.000/2.358.946.303 $(75.609 .618)=121.449$

SHU simpanan (modal) : Sa/TMS (JMA)

$4.762 .438 / 1.940 .880 .720(59.407 .557)=145.771$
Jadi sisa hasil usaha yang diperoleh Rumampuk $\mathrm{CH}: 121.449+145.771=267.217$

Aisyah

SHU jasa : Va/VUK (JUA)

2.277.600/2.358.946.303 (75.609.618) $=73.002$

SHU simpanan (modal) : Sa/TMS (JMA)

$3.442 .230 / 1.940 .880 .720(59.407 .557)=105.361$

Jadi sisa hasil usaha yang diperoleh Aisyah: $73.002+105.361=178.363$

Tambaru

SHU jasa : Va/VUK (JUA)

$3.415 .400 / 2.358 .946 .303(75.609 .618)=109.471$

SHU simpanan (modal) : Sa/TMS (JMA)

$750.127 / 1.940 .880 .720(59.407 .557)=22.960$

Jadi sisa hasil usaha yang diperoleh Tambaru : $109.471+22.960=132.431$

Dst hingga 804 anggota.

Melihat table diatas serta proses perhitungan Sisa Hasil Usaha, maka pembagian Sisa Hasil Usaha telah dilakukan secara proporsional sebanding dengan jasa masingmasing anggota. Semakin tinggi partisipasi anggota baik atas jasa usaha maupun simpanan maka Sisa Hasil Usaha yang diperoleh akan semakin besar.

\section{Pembahasan}

Sebagai suatu badan usaha koperasi didalam menjalankan kegiatan usaha tentu saja menghendaki untuk mendapatkan keuntungan atau Sisa Hail Usaha. Sisa Hasil Usaha yang diperoleh koperasi dibagikan kepada anggota secara proporsional sebanding dengan jasa masingmasing anggota, dimana Sisa Hasil Usaha KSP Berkat Cabang Palopo atas jasa anggota sebesar 15\% dari SHU yang diperoleh koperasi. Dalam hal 
ini ini tidak semua SHU yang diperoleh kopersi dibagi habis karena pembagian SHU dalam Koperasi terbatas sesuai dengan tingkat bunga bank pemerintah dan rapat anggota. SHU yang tidak dibagi dapat digunakan untuk pemupukan modal. Apabila modal bertambah besar maka dengan sendirinya lingkup usaha koperasi akan bertambah besar.

Untuk lebih jelasnya dapat dilihat pada tabel perolehan Sisa Hasil Usaha atas jasa anggota KSP Berkat Cabang Palopo.

\section{Sisa Hasil Usaha Atas Jasa Anggota KSP Berkat Cabang Palopo Tahun 2010-2014}

\begin{tabular}{|c|c|c|}
\hline Tahun & Sisa Hasil Usaha & $\begin{array}{c}\text { SHU Atas Jasa } \\
\text { Anggota }\end{array}$ \\
\hline 2010 & 404.411 .296 & 60.661 .694 \\
\hline 2011 & 634.017 .536 & 95.102 .630 \\
\hline 2012 & 550.553 .816 & 82.583 .072 \\
\hline 2013 & 763.601 .088 & 114.540 .163 \\
\hline 2014 & 900.114 .502 & 135.017 .175 \\
\hline
\end{tabular}

Tabel diatas menunjukkan bahwa dengan meningkatnya SHU yang yang diperoleh koperasi maka SHU atas jasa anggotapun ikut meningkat. Pada tahun 2010-2011 SHU atas jasa anggota meningkat dari Rp. 60.661.694, sampai Rp. 95.102.630 atau $15 \%$ dari SHU yang diperoleh koperasi yaitu Rp. 404.411.296, Rp. 634.017.536. Pada tahun 2012 SHU atas jasa anggota mengalami penurunan hingga Rp. 82.583.072 atau $15 \%$ dari SHU yang diperoleh koperasi yaitu sebesar 550.553.816. Sedangakan pada tahun 2013-2014 SHU atas jasa anggota meningkat dari Rp. 114.540.163 sampai Rp. 135.017.175 atau $15 \%$ dari SHU yang diperoleh koperasi yaitu Rp. 763.601.088, 900.114.502.

\section{SIMPULAN}

1) Dengan meningkatnya Sisa Hasil Usaha yang diperoleh KSP Berkat Cabang Palopo maka Sisa Hasil Usaha atas jasa anggota pun meningkat. Hal ini karena kinerja koperasi yang baik dan mampu menciptakan nilai tambah dari tiap tahunnya.

2) Dengan menggunakan rumus pembagian Sisa Hasil Usaha maka pembagian Sisa Hasil Usaha pada KSP Berkat Cabang Palopo telah dilakukan secara proporsional sebanding dengan jasa masing-masing anggota koperasi. Semakin tinggi partisipasi anggota baik atas jasa usaha maupun simpanan maka Sisa Hasil Usaha yang diperoleh pun akan meningkat.

\section{DAFTAR PUSTAKA}

Anonim. Undang-Undang RI No.17 tahun 2012 tentang Perkoperasian \& UU RI No.20 Tahun 2008 Tentang Usaha Mikro, Kecil dan Menengah. Bandung : Citra Umbara.

Undang-undang Dasar Nomor 25 tahun 1992 tentang Perkoperasian.

Arifin Sitio, Halomoan Tamba. 2001. Koperasi Teori dan Praktik. Jakarta : Erlangga.

Chaniago, Arifinal. 1984. Perekonomian Indonesia. Bandung : Angkasa.

Hendrojogi. 2003. Koperasi Asas-Asas, Teori dan Praktik. Jakarta : PT Raja Grafindo Persada.

Hendar, Kusnadi. 2005. Ekonomi Koperasi. Jakarta : Lembaga Penerbit Fakultas Ekonomi UI.

Muhammad Firdaus, Agus Edhi Susanto. 2004. Perkoperasian Sejarah, Teori dan Praktek. Bojongkerta : Ghalia Indonesia. 
Ninik Widiyanti, Sunindhia. 2003. Koperasi \& Perekonomian Indonesia. Jakarta : PT Rineka Cipta dan PT Adi Aksara.

Pandji Anoraga, Ninik Widiyanti. 2007. Dinamika Koperasi. Jakarta : PT Rineka Cipta \& Bina Andi Aksara.

Subandi. 2009. Ekonomi Koperasi (Teori \& Praktik). Jakarta : Alfabeta.

Sugiyono. 2012. Metode Penelitian Kuantitatif Kualitatif dan $R \& D$. Bandung : Alfabeta.

Novi Hasti Anggraini. 2009. Analisis FaktorFaktor Yang Mempengaruhi Sisa Hasil Usaha Koperasi Pegawai Negeri di Kota Surakarta tahun 2007. Skripsi Fakultas Ekonomi Universitas Sebelas Maret Surakarta.

Lilis Sulistio Wati. 2011. Pengaruh Jumlah Anggota dan Jumlah Simpanan Terhadap Perolehan Sisa Hasil Usaha Pada Koperasi Mitra Putra Bahari di Kabupaten Ende. Skripsi Universitas Pembangunan Nasional "Vetran" Jawa Timur.

http://medianapooh.blogspot.com/2010/10/pengert ian dan prinsip-prinsip koperasi.html 